\title{
Análise dos sistemas computacionais críticos utilizados no controle de tráfego aéreo brasileiro
}

\author{
Francisco Fabrício Ribeiro de Sousa ${ }^{1}$ \\ Sérgio Barros de Sousa ${ }^{2}$
}

\begin{abstract}
Resumo: O controle de tráfego aéreo no mundo é realizado por profissionais chamados controladores de tráfego aéreo, que utilizam equipamentos e sistemas computacionais para garantir a segurança dos voos. Este trabalho apresenta o resultado de uma pesquisa sobre os sistemas utilizados para controle do espaço aéreo brasileiro e os problemas desses, além de apontar melhorias, como um sistema radar baseado em satélite e no sistema Automatic Dependent Surveillance Broadcast - ADS-B, bem como a introdução de strips eletrônicas e "videonuvem", garantindo, assim, uma maior precisão, segurança e qualidade no controle de tráfego aéreo brasileiro.
\end{abstract}

Palavras-chave: Controle de Tráfego Aéreo. Satélite. Sistema Radar.

\begin{abstract}
The air traffic control around the world is done by professionals called air traffic controllers, using equipment and computer systems to ensure the safety of flights. This paper presents the results of a survey of the systems used to control the Brazilian air space and the problems of these, while pointing out improvements, such as a radar system based on satellite and Automatic Dependent Surveillance Broadcast System - ADS-B as well as the introduction of electronic strips and "video cloud" thus ensuring greater accuracy, safety and quality control in the Brazilian air traffic.
\end{abstract}

Keywords: Air Traffic Control. Radar system. Satellite.

\section{Introdução}

Este trabalho, sem apresentar uma abordagem exaustiva do assunto, tem o objetivo de analisar os problemas de tecnologia do controle de tráfego aéreo do Brasil. Para isso, serão apresentadas as características técnicas e as funcionalidades dos sistemas X4000, Sais - Sistema Automatizado de Sala AIS e Sistema Eletrônico de strips. Juntamente com a análise dos instrumentos e controles desses softwares, foram apresentados alguns elementos com vistas a subsidiar a melhoria nos atuais sistemas de controle de tráfego aéreo. É possível observar com essa proposta, que o sistema de controle de tráfego aéreo requer um esforço concentrado na proposição de melhorias ao sistema.

Diante dessa importância, a população do Brasil percebeu que algo estava errado com o setor aéreo, devido a uma crise que ocorreu entre os anos de 2006 e 2007, caracterizada pela imprensa como o "caos aéreo" ou "apagão aéreo".

Importante informar que problemas no setor aéreo tiveram início bem antes de 2006. Empresas aéreas em crise e um regime regulatório ineficiente fizeram o setor chegar ao "apagão aéreo". Embora a crise do setor tenha início antes mesmo de 2006, ela só ficou evidenciada com acidentes aéreos com aeronaves comerciais em 2006 e 2007.

\footnotetext{
${ }^{1}$ Programa de Pós-Graduação em Engenharia de Software, Estácio de Sá, Moreira Campus - Fortaleza (CE) - Brasil

\{franciscofabricios@gmail.com\}

${ }^{2}$ Departamento de Computação, Universidade Estadual do Piauí, Campus Parnaíba - Parnaíba (PI) - Brasil

\{sergiobarrosegmail.com\}
}

http://dx.doi.org/10.5335/rbca.v8i3.6018 
Esses acidentes fizeram com que a sociedade soubesse dos inúmeros problemas enfrentados pelo setor, como problemas de infraestrutura e falha de sistemas e equipamentos utilizados no controle de tráfego aéreo. Diante da importância do setor aéreo, seja essa, econômica, social ou geopolítica, foi realizada uma pesquisa bibliográfica para listar os problemas dos sistemas computacionais atualmente utilizados, bem como a busca por modelos tecnológicos existentes no mundo para controle de tráfego aéreo, mas não adotados pelo Brasil e, assim, apontar possíveis melhorias para possíveis implementações nos sistemas nacionais.

\section{A importância da aviação}

Segundo [1], a República Federativa do Brasil possui uma área 8.515.692,27 km².

Considerando o tamanho territorial do Brasil, [2] expõe que:

[...] a sociedade brasileira depende do transporte aéreo para que os cidadãos exerçam seu direito constitucional de ir e vir em país de extensão continental e de ausência de alternativas viáveis de transporte - o modal ferroviário e de navegação são praticamente inexistentes e o modal rodoviário é ineficiente e inadequado, em virtude da precariedade das rodovias e da dimensão da distância entre destinos.

Sobre a importância do setor aéreo, o estudo [3] informa que:

[...] as viagens aéreas, além de terem reconhecido papel na integração nacional e na indução de negócios entre regiões, também representam um importante insumo produtivo de grande parte das corporações, com relevante impacto na eficiência das cadeias produtivas de diversos setores da indústria brasileira. Além disso, pode-se dizer que o setor promove uma maior inserção internacional do Brasil em termos de fluxos comerciais e culturais.

Desse modo, o setor aéreo fomenta os demais setores da economia, como o turismo.

No que diz respeito ao turismo, [4] enfoca que "o resultado da receita cambial turística nos últimos anos aponta para o fortalecimento da atividade no mercado internacional". Ainda, afirma que "o Brasil registrou uma receita cambial turística de US\$ 5,30 bilhões".

\subsection{Contribuição para o PIB nacional e emprego}

No estudo [5], tem-se que "o setor da aviação contribui R\$ 32.0 bilhões (1,0\%) em relação ao PIB brasileiro". Afirma ainda, que a participação no PIB é ainda maior se incluirmos o turismo quando a revista assegura que "há R $\$ 9.9$ bilhões em benefícios 'catalíticos' através do turismo que aumentam a contribuição global do PIB para 1,3\%", conforme Tabela 1.

O estudo também aponta que "o setor da aviação sustenta 684 mil empregos no Brasil", bem como, que “[...] há mais 254 mil pessoas empregadas através dos efeitos catalíticos (turismo) de aviação", conforme Tabela 1. Para [5], o setor contribuiu com "R\$ 12,6 bilhões" em imposto. Cabe salientar que esse estudo foi baseado nos dados econômicos do ano de 2009.

Diante do que foi exposto anteriormente, cabe então concordar com [6], quando esse afirma que "[...] não serão necessários maiores dados, para que se conclua pela extraordinária importância assumida, nos últimos anos, pela aviação comercial no Brasil, onde figura, presentemente, entre os mais intensos e progressistas meios de transporte de que dispõe o país".

Todavia, embora o setor seja importante para o país, ele vem passando por problemas que fazem com que o setor não amplie sua força. Segundo [3], deveriam ser implantadas “[...] ações que poderiam ampliar a capacidade de processamento de passageiros, capacidade de movimentação de aeronaves, ou ainda, melhora do conforto do passageiro: investimentos em pequenas obras, melhoria das operações aeroportuárias, do controle de tráfego aéreo $[\ldots]$ "... 
Tabela 1: A contribuição de aviação da produção e do emprego para o Brasil

\begin{tabular}{|c|c|c|c|c|c|}
\hline & Direta & Indireta & Induzida & Total & $\begin{array}{c}\% \text { do total da } \\
\text { economia }\end{array}$ \\
\hline \multicolumn{6}{|c|}{ Contribuição para o PIB (BR milhões) } \\
\hline Empresas Aéreas & 5,395 & 3,555 & 2,754 & 11,705 & $0,4 \%$ \\
\hline Aeroportos e Serviços de Terra & 6,176 & 6,138 & 3,774 & 16,088 & $0,5 \%$ \\
\hline Espaço aéreo & 1,728 & 1,79 & 781 & 4,299 & $0,1 \%$ \\
\hline Total & 13,298 & 11,483 & 7,309 & 32,091 & $1,0 \%$ \\
\hline Catalítico (Turismo) & 4,481 & 3,122 & 2,269 & 9,872 & $0,3 \%$ \\
\hline Total incluindo catalítico & 17,780 & 14,605 & 9,578 & 41,963 & $1,3 \%$ \\
\hline \multicolumn{6}{|l|}{ Contribuição para o emprego } \\
\hline Empresas Aéreas & 49 & 103 & 80 & 232 & $0,3 \%$ \\
\hline Aeroportos e Serviços de Terra & 66 & 179 & 110 & 354 & $0,4 \%$ \\
\hline Espaço aéreo & 23 & 52 & 23 & 97 & $0,1 \%$ \\
\hline Total & 138 & 334 & 213 & 684 & $0,7 \%$ \\
\hline Catalítico (Turismo) & 109 & 80 & 65 & 254 & $0,3 \%$ \\
\hline Total incluindo catalítico & 247 & 414 & 277 & 938 & $1,0 \%$ \\
\hline
\end{tabular}

Fonte: Revista Oxford Economics - Benefícios Econômicos do Transporte Aéreo no Brasil 2011

\section{Crise do setor aéreo brasileiro}

\subsection{Falta de investimento no setor e aumento do tráfego aéreo}

As pesquisas demonstram que o setor aéreo é muito importante para a economia do Brasil. Embora o setor seja origem de um grande valor em impostos e empregos, os investimentos nesse campo não são satisfatórios. Sobre essa questão, [7] destaca que "[...] percebeu-se que os investimentos no setor aéreo em equipamentos e em aparelhos de navegação aérea, em construção, expansão e melhorias na infraestrutura aeroportuária, em suas facilidades ou até mesmo no sistema viário de acesso à infraestrutura foram muito tímidos, se não, inexistentes".

Entretanto, o setor aéreo não tem somente problemas de infraestrutura. Para [8], “[...] diante das dificuldades observadas no setor, percebe-se que a infraestrutura e a capacidade de controle não têm acompanhado a demanda. A carência de estudos científicos para orientar uma melhor gestão do transporte aéreo pode ser apontada como um elemento marcante dentro do cenário nacional [...]”.

O país não possui investimentos em estudos para o setor, ficando, consequentemente, dependente de outros países, principalmente tecnologicamente. Além disso, segundo [9], "o tráfego aéreo brasileiro aumentou sensivelmente nos últimos anos e tem previsão de aumento acima da média mundial para as próximas duas décadas, chegando a 7,3\% ano". [7] informa que "a capacidade das infraestruturas aeroportuárias brasileiras e o sistema de controle de tráfego aéreo não têm acompanhado o crescimento do transporte aéreo, supersaturando dessa forma o sistema”.

\subsection{Apagão aéreo}

Com o aumento do tráfego aéreo e com escassos investimentos em sistemas para um melhor controle das aeronaves, ocorreram dois acidentes aéreos no território brasileiro. Um em 2006, com uma aeronave da Gol Linhas Aéreas e outro em 2007, com uma aeronave da TAM Linhas Aéreas, período citado anteriormente como "apagão" aéreo.

[10] destacam que os problemas identificados durante o "apagão aéreo" foram "falhas técnicas nos equipamentos de controle aéreo". Eles ainda incluem que os "controladores levantaram, na imprensa, problemas relacionados à qualidade dos equipamentos e do sistema de monitoramento de voos". [11] apontam que "[...] o 
setor tem vivido uma crise sem precedentes, deflagrada com a trágica queda de um avião da Gol em setembro de 2006, que trouxe à tona uma série de problemas enfrentados pelo setor, tais como: [...] falhas de cobertura eletrônica por parte dos radares[...]".

Já foi descrito aqui o acidente com a aeronave da Gol. Após esse acidente, os controladores de tráfego aéreo iniciaram a operação-padrão, fazendo muitos voos atrasarem. [12] descrevem que "[...] este recente movimento dos controladores de voo no Brasil expressa mobilização contra as condições vigentes de trabalho: jornadas prolongadas e estressantes, problemas e defasagens nos equipamentos de trabalho [...]”.

Além desses problemas tecnológicos, consequentemente, há outro tão importante quanto esse: o fator humano. Embora não seja foco deste trabalho, vale relatar o que [12] concluem. Segundo elas "ter de desconfiar das máquinas com as quais se opera significa, sem dúvida, potencializar o sofrimento psicofísico e acumular estresse".

Percebe-se que, embora a aviação contribua de forma significativa para a economia do país, os investimentos no setor não são expressivos, a ponto de não haver estudos para a modernização nesse campo, o que fez com que a aviação chegasse a uma crise, gerando problemas, principalmente em relação à tecnologia.

\section{Controle de tráfego aéreo}

Todos os dias, milhares de voo ocorrem no espaço aéreo brasileiro. São centenas de aeronaves em nossos céus, dos mais variados tipos e tamanhos. Evidentemente, torna-se necessária a utilização de recursos humanos e tecnológicos para que os voos ocorram tranquilamente.

[13], em seu trabalho "O controle de tráfego aéreo brasileiro entre setembro de 2006 e março de 2007: a ruptura operacional, o modelo administrativo e perspectivas" afirma que:

O Sistema de Controle do Espaço Aéreo Brasileiro (Sisceab) é um conjunto sociotécnico composto por trabalhadores altamente especializados e por uma tecnologia específica para administrar a fluidez e segurança ao se utilizar o espaço aéreo brasileiro para trânsito de aeronaves ou operações militares em tempo de paz. O órgão central que o gerencia é o Departamento de Controle do Espaço Aéreo (Decea).

Já [14] em seu estudo "Uma abordagem ergonômica em Controle de Tráfego Aéreo em função das inovações tecnológicas" define que:

[...] o trabalho de controle de tráfego aéreo é um eixo fundamental em termos de segurança de voo, pois é através dele que as aeronaves recebem instruções para a realização de um voo seguro. As instruções são resumidas em dados para garantir separações que evite rotas conflitantes, colisões de quaisquer natureza e áreas de restrições, além da detecção e geração de informações meteorológicas.

Em “O Modelo de Controle do Espaço Aéreo Brasileiro e sua Integração com outros Sistemas” (2008), do autor [15], tem-se que o controle de tráfego aéreo é:

[...] uma atividade de origem relativamente recente que, no Brasil, começou oficialmente em 1939. Conta a história que, no legendário Campo dos Afonsos (Rio de Janeiro) colocou-se, sobre uma mesa, os meios básicos: um rádio transmissor, um receptor de frequência variável e um altímetro de avião. Direção e velocidade do vento eram determinados através de uma biruta, de forma semelhante ao que ainda hoje se pratica em muitos aeródromos do interior.

\subsection{Controlador de tráfego aéreo}

No setor aéreo, existe um profissional responsável por manter vigilância e segurança dos voos, o controlador de tráfego aéreo. [10], no artigo "A crise do transporte aéreo - 2006 e 2007”, explicam que "[...] a função dos controladores de voo consiste em emitir, dar instruções e informações necessárias, dentro do espaço 
aéreo de sua jurisdição, com o objetivo de prevenir colisões entre aeronaves e obstáculos nas imediações dos aeroportos".

[16] asseguram que:

Os controladores de tráfego aéreo são os profissionais que fornecem indicações e autorizações de voo, a partir de dados obtidos por radares e dos equipamentos de auxílio à navegação, dos dados meteorológicos e do tratamento dessas informações. As indicações podem estar relacionadas à rota, altitude ou velocidade propostas pelo operador da aeronave, dentre outros itens.

Logo, o controlador de tráfego aéreo pode trabalhar em diversos órgãos de controle. É esse profissional que autoriza as aeronaves a pousar, decolar, desviar de outras aeronaves em conformidade com [17], fazendo, assim, com que os voos sejam tranquilos.

\section{2 Órgãos de controle de tráfego aéreo}

Segundo [18] "são órgãos de controle de tráfego aéreo, o Serviço de Controle de Área (ACC); o Serviço de Controle de Aproximação (APP); e o Serviço de Controle de Aeródromo (TWR)".

Conforme [19]:

O primeiro serviço é prestado pelo Centro de Controle de Área que controla as aeronaves em rota. Já o segundo, é de responsabilidade do Centro de Controle de Aproximação e controla as aeronaves que estão chegando ou saindo nas proximidades dos aeroportos e o último serviço é feito pela Torre de Controle, que tem por objetivo o controle das aeronaves durante a aproximação final e na saída imediata do aeródromo (pontos de origem e destino destinados para pouso e decolagem de aeronaves).

[20] afirmam que "com a área oceânica, que se estende até o meridiano $10^{\circ} \mathrm{W}$, a área total de cobertura do espaço aéreo brasileiro é de 22 milhões de $\mathrm{km}^{2}$ ". De tal modo, [8] informam que "devido à grande extensão da área de controle sob jurisdição do Brasil, cerca de 22 milhões $\mathrm{km}^{2}$, este foi subdividido em cinco regiões de informação de voo (FIRs) as quais são administradas pelos CINDACTA I, II, III e IV (Centro Integrado de Defesa Aérea e Controle do Espaço Aéreo)".

Sobre os CINDACTA [18] acrescenta que: “os CINDACTA's estão divididos em quatro áreas compreendendo todo o espaço aéreo brasileiro: CINDACTA I, II, III e IV, localizados respectivamente em Brasília, Curitiba, Recife e Manaus". Sobre as FIR, o autor [21] explica que "uma FIR, ou Região de Informação de Voo, é dimensionada [...]" conforme a Figura 1.

Esse mesmo autor afirma que as FIR são:

FIR Brasília (FIR-BS), de responsabilidade do CINDACTA I, FIR Curitiba (FIR-CW), de responsabilidade do CINDACTA II, FIR Recife (FIR-RE) e FIR Atlântico (FIR-AO), de responsabilidade do CINDACTA III e FIR Amazônia (FIR-AZ), de responsabilidade do CINDACTA IV.

Vale lembrar, conforme [15], que:

[...] a eficácia do serviço de Controle de Tráfego Aéreo dependerá da disponibilidade e do desempenho dos meios de comunicação, de navegação e de vigilância, bem como da adequação dos demais recursos técnicos instalados nos órgãos de controle e da qualificação dos recursos humanos, incluindo os controladores de tráfego aéreo.

Portanto, o controle de tráfego aéreo se dá por diversos órgãos e serviços de tráfego aéreo. Ressalta-se que tanto os órgãos quanto os serviços necessitam do controlador de tráfego aéreo. Esse profissional presta o serviço de controle a todas as aeronaves que estejam voando em território nacional, baseado nas informações importantes como as meteorológicas, visualização radar e outras. Também, é responsável por dar instruções às aeronaves para que essas evitem áreas perigosas ou tráfego de aeronaves conflitantes para assim realizarem um voo seguro.

Revista Brasileira de Computação Aplicada (ISSN 2176-6649), Passo Fundo, v. 8, n. 3, p. 66-84, abr. 201670 
Figura 1: Regiões de informação de voo no Brasil

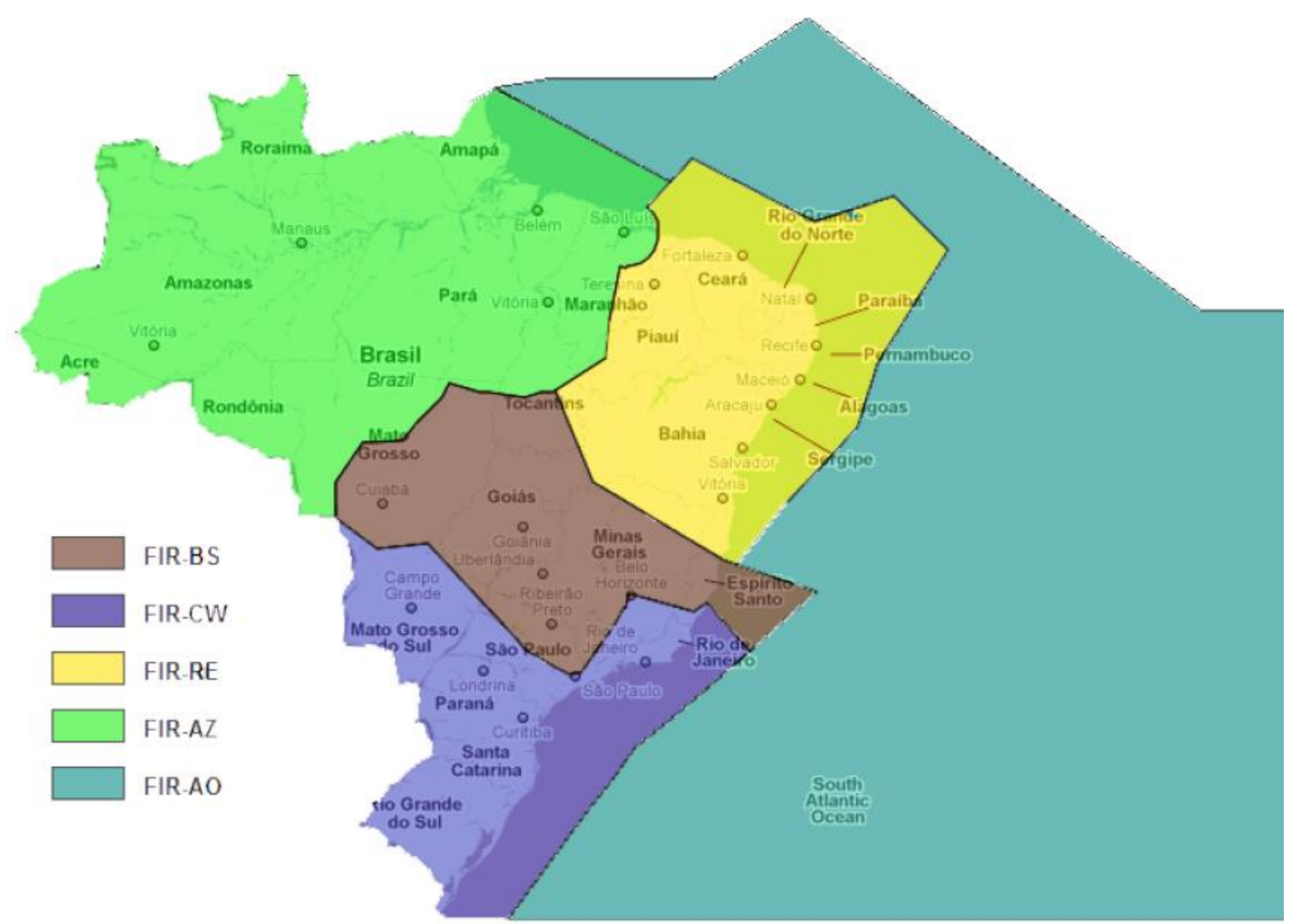

Fonte: "Decisão colaborativa com utilização de Teoria dos Jogos para o sequenciamento de partidas em aeroportos" $(2013)^{3}$

\section{Análise dos sistemas utilizados no controle de tráfego aéreo}

Os controladores de tráfego aéreo necessitam de informações para executarem o serviço e manter seguras as aeronaves em voo. Para que essas informações estejam à disposição desses profissionais, existem sistemas que difundem dados necessários ao sistema de controle de tráfego aéreo.

\subsection{Sistema $X-4000$}

O principal sistema de controle de tráfego aéreo, conforme [22] é "o Sistema de Tratamento e Visualização de Dados (STVD), formalmente denominado X-4000”.

$\mathrm{O}$ [23] explica que:

O X-4000, objeto da auditoria, é o sistema utilizado nos centros de aproximação e de controle de área para apoiar os controladores de voo na prestação do serviço de vigilância radar. É responsável por receber e tratar os dados provenientes dos equipamentos radares, conjugá-los com os dados provenientes dos planos de voo das aeronaves e gerar a visualização das informações necessárias à prestação do serviço de controle de tráfego aéreo.

Note-se que o X-4000 é um sistema que recebe e trata dados que são originados dos radares e plano de voo.

\footnotetext{
${ }^{3}$ RIBEIRO, Vitor Filincowsky. Decisão colaborativa com utilização de Teoria dos Jogos para o sequenciamento de partidas em aeroportos. UNB, 2013. Disponível em: <http://repositorio.unb.br/handle/10482/13661 >.
} 


\subsection{Plano de voo e sistema automatizado de sala AIS - Sais}

Sobre o plano de voo, [24] explica que "[...] o plano de voo é um documento especifico que contém informações relacionadas com um voo planejado de uma aeronave, ou com parte do mesmo, que são fornecidas aos órgãos que prestam serviços de tráfego aéreo [...]".

Para que o X-4000 receba dados de um plano de voo é necessário um sistema. O processamento do plano de voo começa numa Sala AIS. [22] afirmam que "[...] a apresentação do plano de voo deve ser realizada pessoalmente na Sala AIS [...]”. As Salas AIS (Aeronautical Information Service) são órgãos localizados nos aeroportos que recebem os planos de voo (também chamados pelas letras PLN).

O sistema que recebe esse plano de voo é o Sais - Sistema Automatizado de Sala. [24] assegura que "a principal finalidade do Sais é receber do piloto o PLN".

\subsection{Strip}

Do plano de voo serão retiradas algumas informações para o controle de tráfego aéreo para a geração da strip. Em [25], tem-se que "as strips são tiras de papel retangular $(20 \mathrm{~cm} \times 3 \mathrm{~cm})$ em que constam informações sobre as aeronaves, como: identificação, hora estimada de pouso, nível de voo [...]". As autoras ainda complementam "a partir do plano de voo, as strips impressas são usadas principalmente para: adquirir informações, registrar as instruções dadas a um piloto (ou qualquer outra informação necessária) [...]”".

\subsection{Funcionamento do radar atual}

O X-4000 também recebe informações do Radar. O Radar (Radio Detection and Ranging), nada mais é, conforme [15], do que "um sistema que permitiria vigiar o movimento dos aviões no espaço aéreo".

A respeito do seu funcionamento, segundo [26] e [15] vê-se que: "emitindo pulsos poderosos de energia de rádio e detectando os ecos emitidos, era possível descobrir os aviões entrantes a distância considerável [...]". Conforme é mostrado na Figura 2. [15] relata também outra informação que o X-4000 processa: o transponder. Então, o autor afirma que "o transponder é um transmissor-receptor de radar secundário de bordo que, automaticamente, recebe sinais de rádio dos interrogadores de solo e, seletivamente, responde, com um pulso ou grupo de pulsos [...]", conforme pode ser visualizado na Figura 2.

Os autores [15] e [26], embora em trabalhos diferentes, concordam que "[...] os serviços de tráfego aéreo se valem intensamente dos 'alvos' radar, que nada mais é do que a indicação observada numa tela radar resultante do retorno de um sinal emitido por radar [...]". Desse modo, o atual sistema de vigilância radar se dá conforme figura 3 .

O sistema atual de vigilância Radar é feito por meio da comunicação por voz via ondas de rádio (HF e VHF) para que os controladores de voo expressem as instruções como, por exemplo, requerimento para que uma aeronave suba ou desça. Já a antena radar gira em torno de si constantemente, enviando um pulso e recebendo o retorno desse sinal, que será processado pelo sistema de controle de tráfego aéreo. 
Figura 2: Funcionamento do Radar

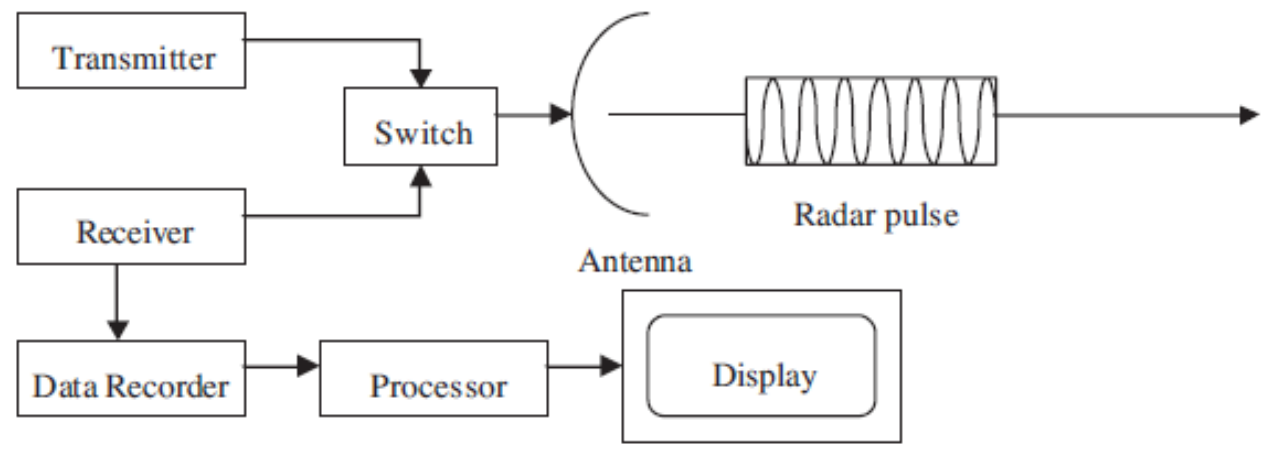

Fonte: An Introduction to Synthetic Aperture Radar (SAR) Progress In Electromagnetics Research B ${ }^{4}$

Figura 3: Demonstração do funcionamento do radar e comunicações de controle de tráfego aéreo

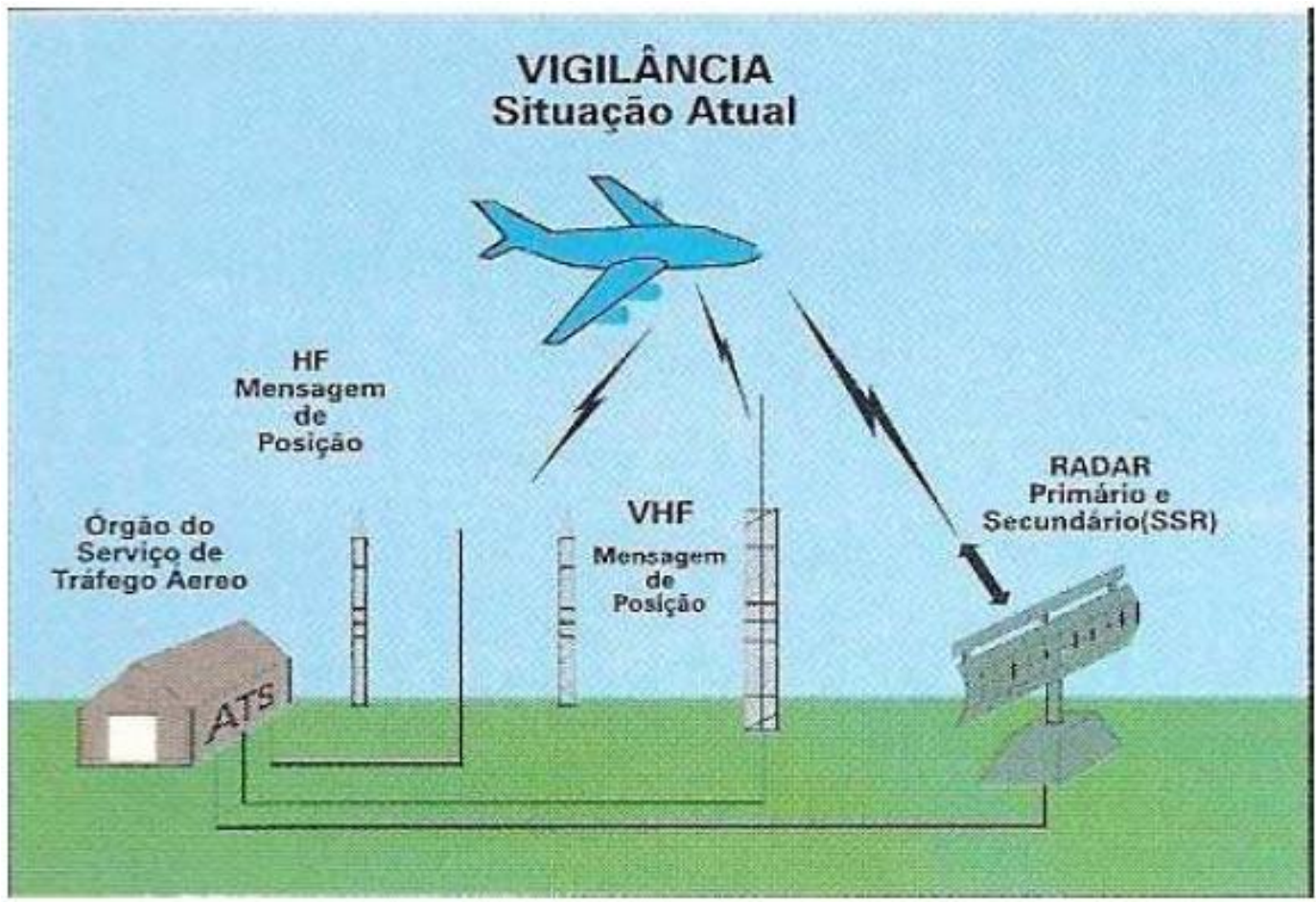

Fonte: Metodologia para a organização de um banco de dados com aplicativos para o planejamento de voo $(2008)^{5}$

\subsection{Integração do X-4000 com o Sais e o Radar}

O X-4000, que é o sistema de controle de tráfego aéreo instalado nos centros de controle do Brasil, processa as informações recebidas do plano de voo e radares primário e secundário, retornando o resultado para

${ }^{4}$ CHAN, Y. K; KOO, V. C. An Introduction to Synthetic Aperture Radar (SAR). Progress In Electromagnetics Research B, Vol. 2, 27-60, 2008. Disponível em: 〈http://www.jpier.org/PIERB/pier.php?paper=07110101>.

5 GUERRA, José Ricardo Gramelich. Metodologia para a organização de um banco de dados com aplicativos para o planejamento de vôo. 2008. 87 f. Monografia (Especialização em Gestão da Aviação Civil)Universidade de Brasília, Brasília, 2008. Disponível em: < http://bdm.unb.br/handle/10483/1614>. 
uma tela com identificação, posição, velocidade e altitude da aeronave, bem como se ela está subindo, descendo ou mantendo sua altitude. A tela com esses dados pode ser visualizada na Figura 4.

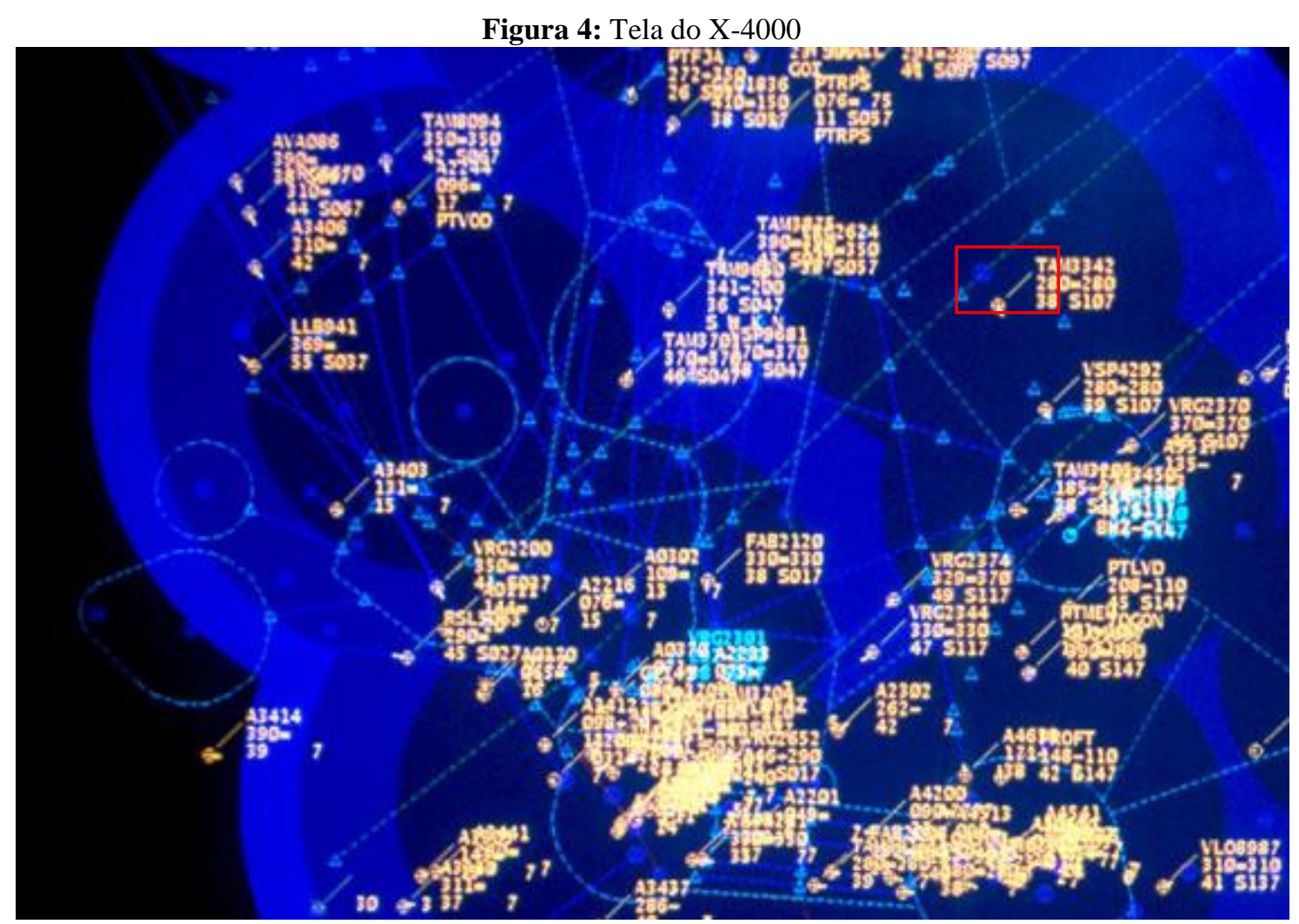

Fonte: Departamento de Controle do Espaço Aéreo

$\mathrm{Na}$ Figura 4, é demonstrado um videomapa, com o que se denomina de etiqueta radar (contornado de vermelho), que fornece ao controlador de tráfego aéreo a visualização do posicionamento de cada aeronave voando em sua área de controle com as informações anteriormente citadas.

Outro problema, observado no sistema atual, é seu tempo de desenvolvimento que o torna obsoleto, com base nessa análise, [8] afirmam que "os sistemas convencionais de navegação aérea de hoje, utilizam tecnologia de $1946[\ldots] ”$.

Além disso, o Brasil não possui tecnologia própria para sistema de radares. Em [27] é encontrado que "enquanto os três primeiros CINDACTAs utilizam tecnologia francesa da empresa Thales (antiga ThompsonCSF), o CINDACTA IV (Projeto SIVAM) adota equipamentos de empresas norte americanas [...]”.

A partir dessa análise, observa-se que o país necessita ter uma produção própria de radares e sistemas para visualização, com vistas a reduzir custos e burocracia com a aquisição e manutenção desses equipamentos. No entanto, [28] já advertem que “[...] a complexidade e capacidade desses sistemas podem não ser capaz de acompanhar o ritmo de crescimento do setor".

Porém, [29] entende que "o sistema de controle de tráfego aéreo (ATC - Air Traffic Control) atual baseia-se em auxílios de navegação terrestres, sistema RADAR e comunicação por voz, que já não atendem satisfatoriamente à demanda atual da aviação civil”"

Sobre o sistema de radar atual [15] apresenta também os seguintes problemas: "possui limitações de alcance, custos de instalação (vários milhões dólares) e manutenção, além das dificuldades de encontrar sítio apropriado para a instalação que, em muitos casos, o tornam uma ajuda menos desejável para fins de gerenciamento do tráfego aéreo civil". Sobre a limitação de alcance dos radares [30] afirmam que, "portanto, podemos ter áreas controladas onde não há cobertura radar" e [31] complementam que "devido às características do relevo de uma região, a cobertura do sinal de um radar varia de uma posição de instalação para outra, 
podendo apresentar lacunas". Na época do acidente envolvendo a aeronave da Gol Linhas aéreas um dos problemas encontrados segundo [18] foi "[...] falhas de cobertura radar [...]".

\subsection{Automatic Dependent Surveillance Broadcast- ADS-B}

Conforme [28] afirmam que:

O ADS-B é um sistema de vigilância, como o radar, mas oferece maior precisão e serviços adicionais, como informações sobre o clima e trafego, ele prove aos controladores aéreos e pilotos informações muito mais precisas que ajudem a manter as aeronaves em distancias seguras no céu e nas pistas de decolagem. O funcionamento baseia-se no transponder da aeronave que recebe um sinal GPS e o utiliza para determinar a localização precisa da aeronave no céu, essas informações são combinadas com outros dados e transmitidas a outros aviões e controladores aéreos.

Como é demonstrado na Figura 5.

Figura 5: Funcionamento do ADS-B

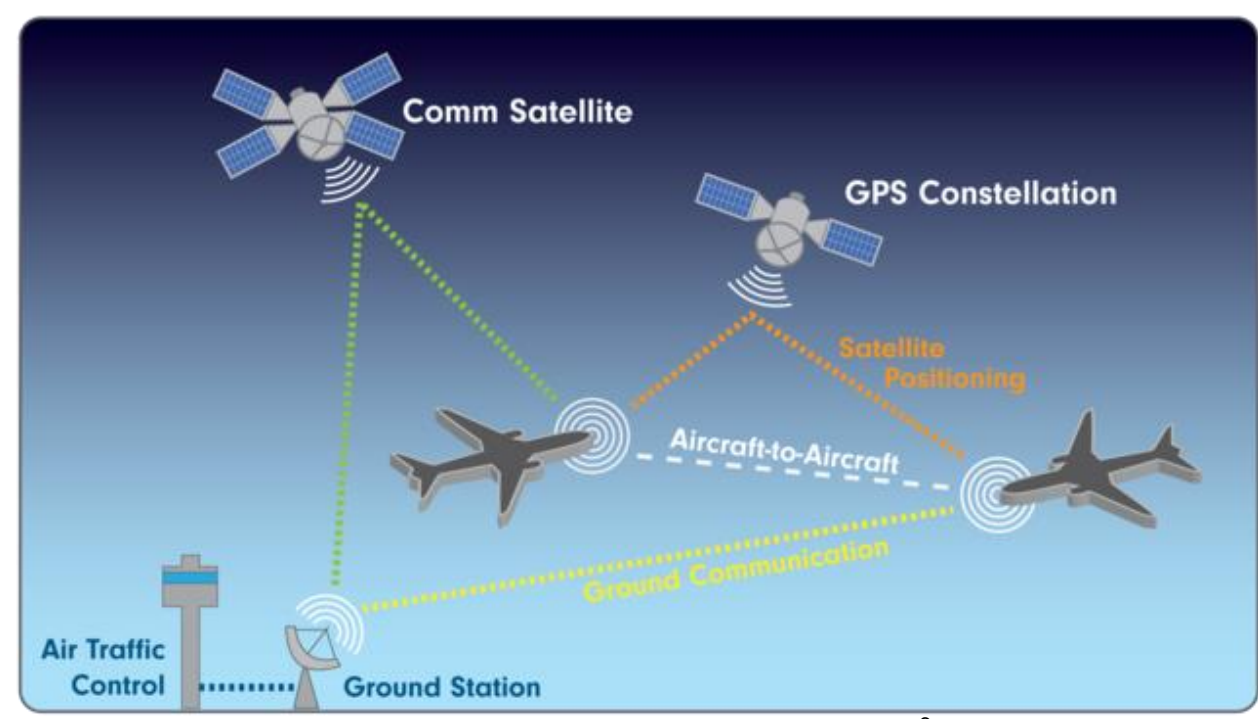

Fonte: Imagem extraída do site Pyevolve ${ }^{6}$

Uma vantagem do sistema RADAR baseado em ADS-B é explicada por [32]. Segundo eles "a tecnologia ADS-B propicia o aumento da segurança, fazendo que aeronaves equipadas com o dispositivo, se tornem visíveis em tempo real ao Air Traffic Controll - ATC, disponibilizando os seus dados de velocidade e posição transmitidos a cada segundo, ao contrário do radar secundário, que leva em torno de 12 segundos".

[31] explicam que:

A arquitetura utilizada com essa tecnologia é composta por ADS-B Out e ADS-B In. O ADS-B Out consiste de um equipamento componente aviônico, localizado dentro do transponder da aeronave, transmitindo os dados em tempo real, por meio de frames codificados. Neste caso, os dados enviados pela aeronave são: identificação (prefixo); posição atual (latitude/longitude); altura; proa; velocidade; e razão de subida e descida (climb). O ADS-B In consiste de um receptor em terra, que captura estes dados (ground-airtraffic); ou embarcado na aeronave (air-airtraffic).

Como é demonstrado na Figura 6.

[31] explicam ainda que:

${ }^{6} \mathrm{http} / / /$ pyevolve.sourceforge.net/wordpress/?tag=ads-b 
O funcionamento da arquitetura do ADS-B é semelhante ao do transponder mode C. No modo de funcionamento (mode) $\mathrm{C}$, o transponder, ao receber o sinal vindo do radar no solo, envia de volta um sinal de resposta codificado com os dados da velocidade, altitude e sentido do deslocamento da aeronave. Estes dados são disponibilizados na tela da aeronave, via software do radar virtual. O ADS-B Out transmite os dados para as estações receptoras ADS-B In [...].

Portanto, temos que o sistema, conforme [31]:

Ao contrário do transponder, o ADS-B depende de estações receptoras de rádio, coletando os sinais transmitidos. Estes sinais, após recebidos, são decodificados e dirigidos aos vários setores responsáveis pelo processamento tais como: controladores do tráfego de saída ou de chegada de aeronaves; centros de operações; empresas aéreas gerenciadoras de cargas e/ou passageiros; ou outras aeronaves compartilhando as rotas voadas.

Figura 6: Representação do aviônico ADS-B Out e interfaces com demais equipamentos

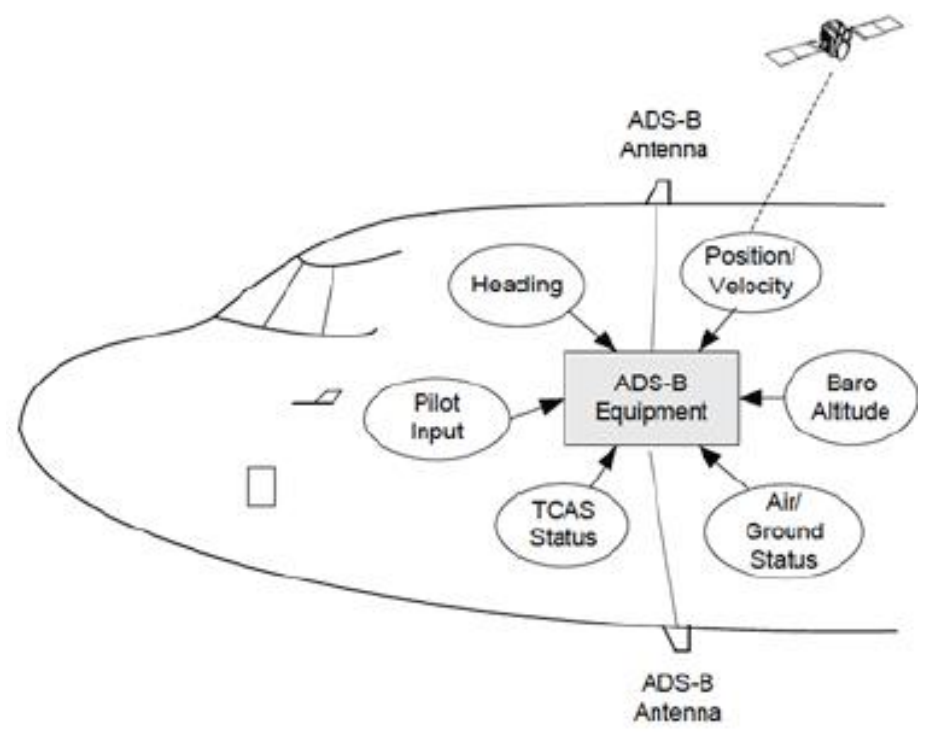

Fonte: Um modelo de aplicação do receptor ADS-B brasileiro para antecipação de ventos aeroportuários ${ }^{7}$

\section{Radar via satélite baseado em ADS-B}

Juntamente com as análises apresentadas até o momento, para melhoria e modernização do sistema radar atual, acredita-se que o modelo de sistema computacional radar baseado em ADS-B com transmissão via satélite seria uma solução para modernização e ganho de informações precisas e em tempo quase real (devido ao delay de transmissão e recepção dos dados de voo).

Sendo assim, haveria a necessidade de um equipamento aviônico instalado na aeronave que apanharia as informações de posição por GPS da aeronave e a matrícula da aeronave, bem como as informações dos demais equipamentos da aeronave como velocidade, nível de voo, código transponder, o qual transmitiria tais informações para um ou mais satélites que, por sua vez, as enviariam para um satélite. Os centro de controle de

COSTA, Rodrigo Pintus Gonçalves da; FALCÃO, Jonatas Barros; CUNHA, Adilson Marques da; CORREIA, Anderson Ribeiro; DIAS, Luiz Alberto Vieira. Um modelo de aplicação do receptor ADS-B brasileiro para antecipação de ventos aeroportuários. XI SITRAER - SIMPÓSIO DE PESQUISA EM TRANSPORTE AÉREO. Brasília: 2012. Disponível em: < http://www.sysport.com.br/Papers/XI\%20Sitraer.pdf> 
tráfego aéreo, receberiam essas informações por meio de uma antena parabólica conforme é disposto na Figura 7.

Figura 7: Funcionamento da arquitetura radar via satélite baseando em ADS-B

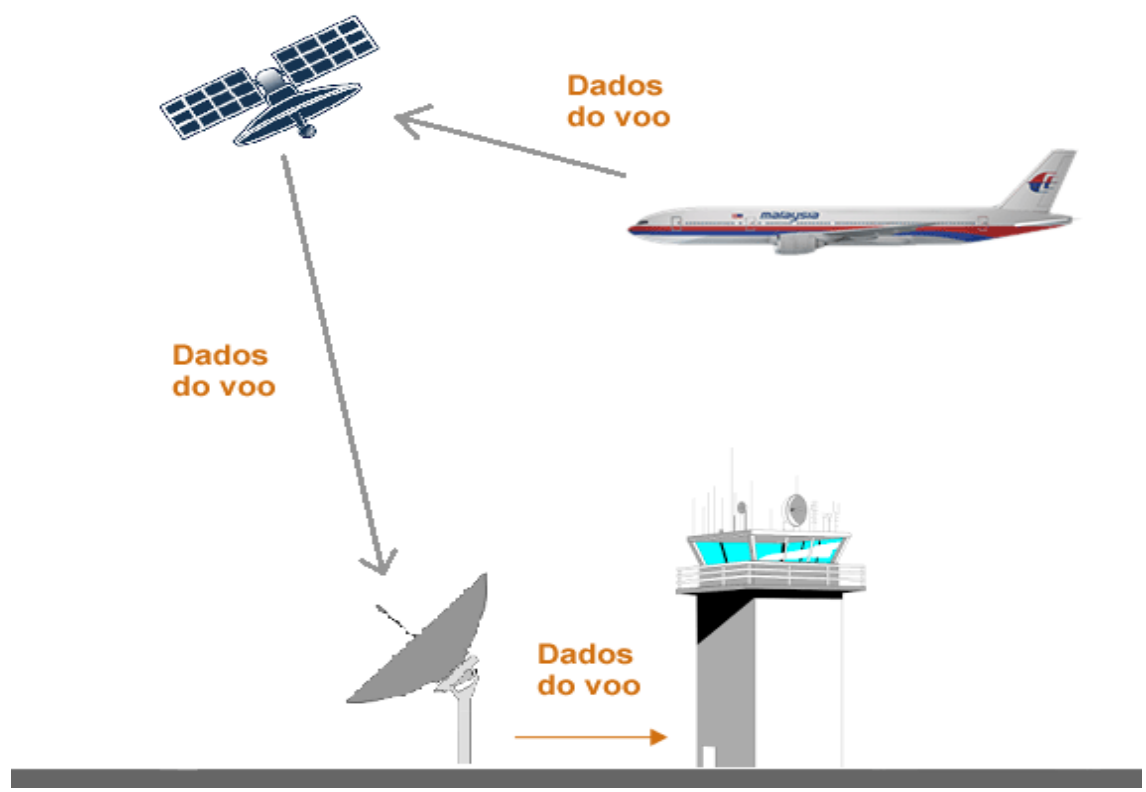

Fonte: Elaborada pelos autores

\section{Strips eletrônicas com radar via satélite baseado em ADS-B}

Em [33] vê-se que:

As strips eram originariamente escritas à mão e atualizadas, também manualmente, depois de contato radio com o piloto da aeronave. Atualmente, com a automação dos sistemas, as informações das strips chegam por diversos meios e são transferidas para um banco de dados que gerencia as informações, podendo assim a strip ser impressa a qualquer momento. Depois de impressa, e já disposta no strip board é comum que o controlador a atualize manualmente. Nos novos sistemas automatizados, em especial o novo sistema que está sendo implantado no Brasil, o trabalho de controle é feito através de strips eletrônicas. A informação chega direto do banco de dados para o monitor (display) que fica localizado ao lado da tela do radar.

Logo, é possível perceber um problema. São dois displays, um para mostrar o sistema radar e outro para o sistema de strip. Uma ferramenta eficiente apresentaria o radar e as strips juntos em uma mesma tela e, assim, todas as informações relativas às aeronaves que estivessem voando em determinada área de controle seriam encontradas conjuntamente.

Portanto, julga-se que a junção de um sistema radar baseado em ADS-B com o sistema de strip aperfeiçoe e agilize o serviço do controlador de tráfego aéreo, disponibilizando, ao mesmo tempo, a visualização das aeronaves que estiverem voando em sua área de jurisdição, bem como as strips, conforme a Figura 8.

Na Figura 9, observa-se ao lado esquerdo, o radar, no qual é possível visualizar as aeronaves voando na área controlada. Do lado direito são visíveis as strips das aeronaves que aparecem no radar. Nas strips, é possível visualizar a identificação e as informações importantes para o controlador de tráfego aéreo como, por exemplo, altitude, posição e velocidade das aeronaves, identificação da aeronave. 
Figura 8: Modelo de sistema radar com strips eletrônicas

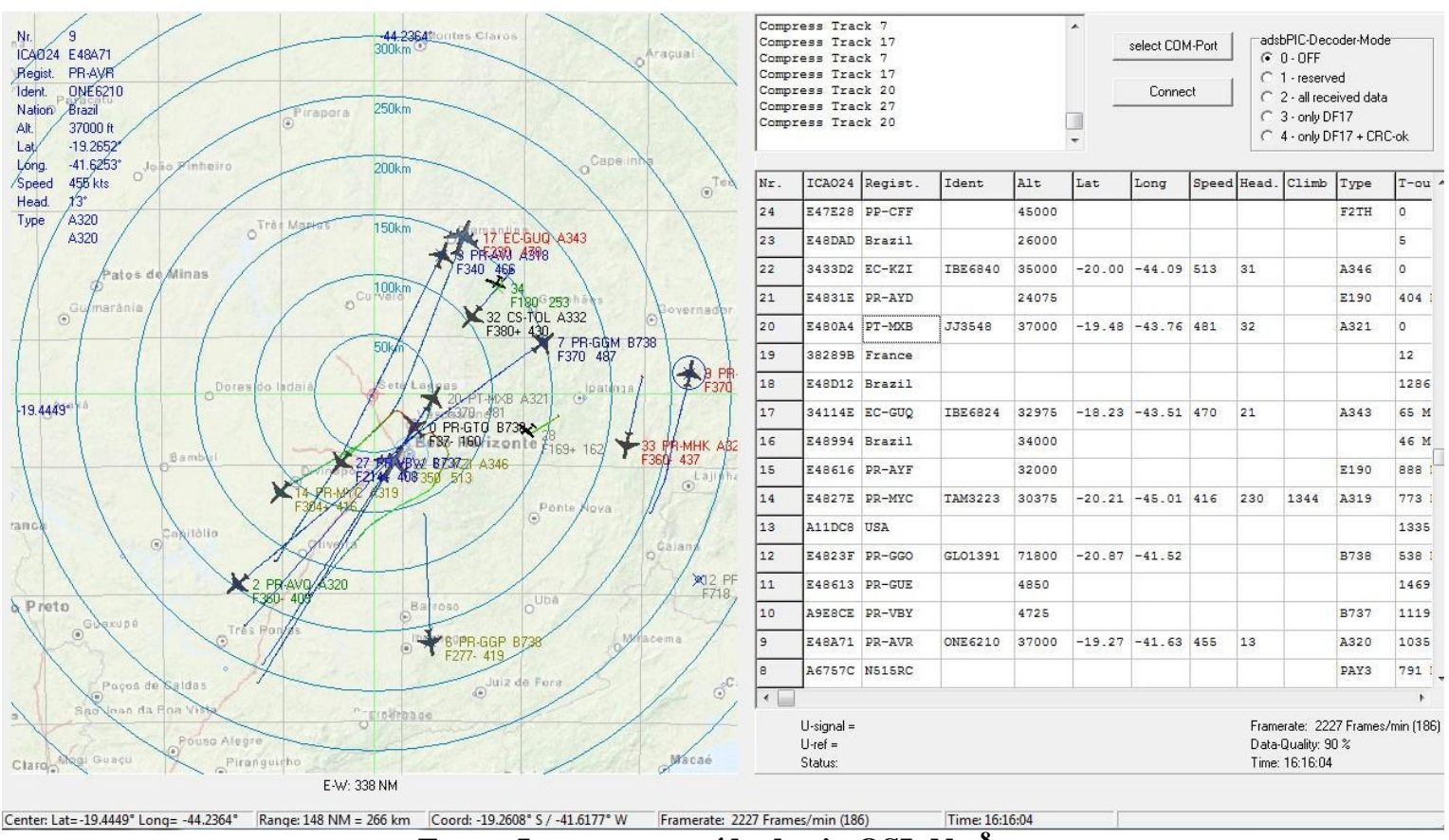

Fonte: Imagem extraída do siteQSL.Net ${ }^{8}$

\section{Videonuvem no radar via satélite baseado em ADS-B}

Outro sistema importante é o meteorológico. [21] afirma que os órgãos de meteorologia aeronáutica fornecem "dados de previsão e/ou de observação dos fenômenos meteorológicos referentes às respectivas áreas de jurisdição, quando solicitados". São os CMV - Centro Meteorológicos de Vigilância. Há quatro Centros Meteorológicos de Vigilância no País. Eles operam associados aos Centros de Controle de Área (ACC) e são responsáveis pela vigilância das condições meteorológicas que afetam as operações aéreas, dentro da FIR de sua responsabilidade.

Existem alguns problemas com esse sistema, os quais são relatados a seguir. O CMV tem radares meteorológicos, imagens de satélite e um banco de dados com informações meteorológicas de todos os aeroportos do Brasil, porém, os controladores não possuem acesso direto a esses dados, os profissionais apenas recebem alerta dos CMV ou respondem às consultas sobre condições meteorológicas solicitadas pelos controladores.

Além disso, [23] apresenta que "os controladores de voo do controle de aproximação do Rio de Janeiro apontaram informações importantes para o serviço de vigilância radar que o sistema X-4000 não apresentava, à época da auditoria, tais como a grade de altura mínima de setor, a videonuvem [...]”.

Sendo assim, para atendimento a esses requisitos, seria necessário implementar nesse novo Sistema Radar uma ferramenta ou função que disponibilizasse na tela de radar do controlador de tráfego aéreo a opção de visualização das nuvens presentes em sua área de controle e uma escala de dBZ, conforme Figura 9. Essa função não permaneceria ativa na tela do radar. Somente seria visualizada caso o controlador de tráfego aéreo venha a ativar a função.

Segundo [33], "o dBZ é o fator de refletividade que mede a intensidade do eco. Quanto maior for o dBZ, maior será a intensidade da formação". Portanto, quanto maior o valor em $\mathrm{dBZ}$, maior será a intensidade da formação, de turbulência, da formação de gelo e tempestades. Consequentemente, esse aumento de unidades de $\mathrm{dBZ}$ evidenciam uma situação de risco para as aeronaves, o que deve ser evitado, logo, uma melhoria dessa

${ }^{8}$ http://www.qsl.net/py4zbz/adsb.htm 
ferramenta significaria uma evolução no trabalho de controle de tráfego, o que seria refletido significativamente no nível de segurança da aviação.

Figura 9: Modelo de Sistema Radar com nuvens baseado em ADS-B

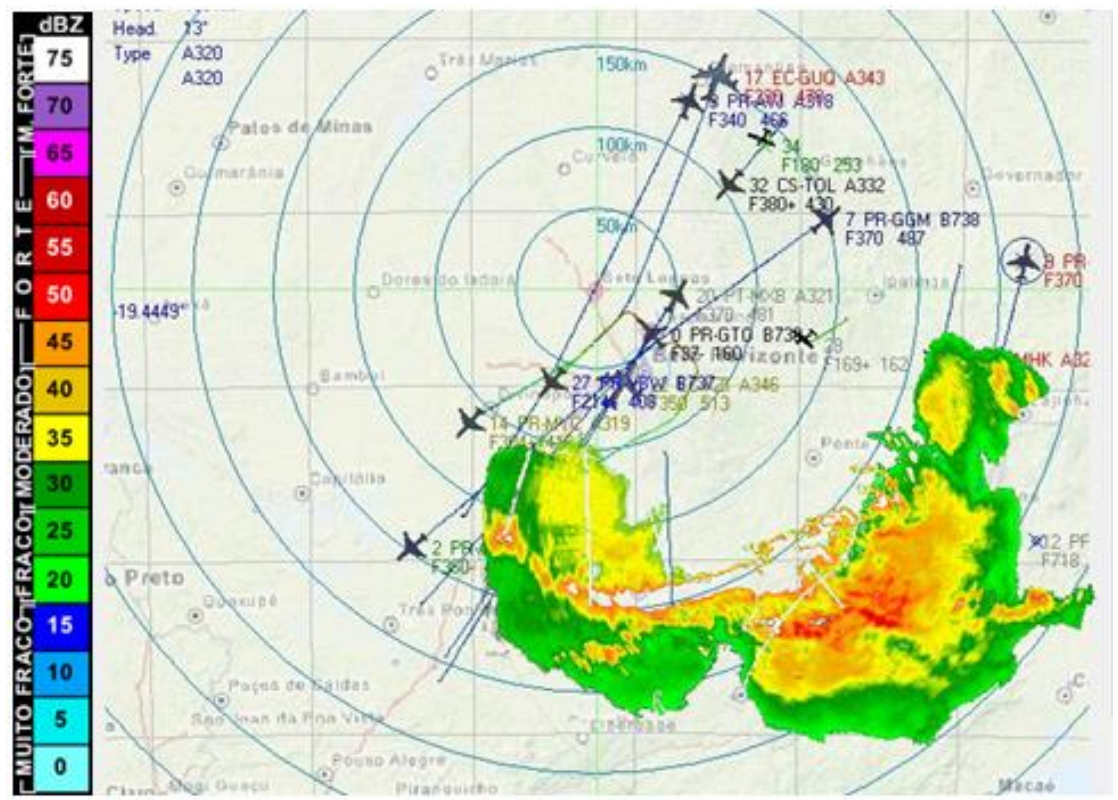

Fonte: Imagem adaptada do siteQSL.Net pelos autores ${ }^{9}$

\section{ADS-B no controle de tráfego aéreo mundial}

A aviação civil passa por uma evolução, conforme apresentado por [35]: "na Aviação Civil ocorre uma transição entre o modelo de navegação vigente no século XX, baseado em auxílios em terra, por um modelo que utiliza auxílios por satélite, com especial ênfase nos sistemas de posicionamento global".

A implantação do ADS-B para auxílio no controle de tráfego aéreo no mundo é uma tendência. Segundo [36]: "[...] observou-se que diversos países, com destaque para Austrália e Estados Unidos, estão com cronogramas avançados quanto ao desenvolvimento e implantação de seus sistemas de vigilância ADS-B".

Para [37]: "[...] o ADS-B está a ser utilizado para monitorizar o tráfego no Golfo do México, local onde não existia nenhum sistema de vigilância nessa área". Ela afirma, igualmente, que: "ainda nos EUA, zonas sem cobertura radar, ou com cobertura deficiente, como por exemplo Filadélfia, Ontário, Golfo do México e Havaí são candidatas a receber esse sistema de vigilância, em que já estão a decorrer ensaios ADS-B". Em seu trabalho, [37] mostra como estava a implantação do ADS-B nos Estados Unidos em 2010, conforme Figura 10.

Seguindo a tendência mundial de implantação do ADS-B, a Europa também tem um programa para implementação, chamado CASCADE. Segundo [37]: "o programa CASCADE coordena a implementação europeia do ADS-B [...]". Ainda segundo [37] a área de desenvolvimento do ADS-B na Europa está conforme a Figura 11.

\footnotetext{
${ }^{9}$ http://www.qsl.net/py4zbz/adsb.htm
} 
Figura 10: Locais de Implementação ADS-B

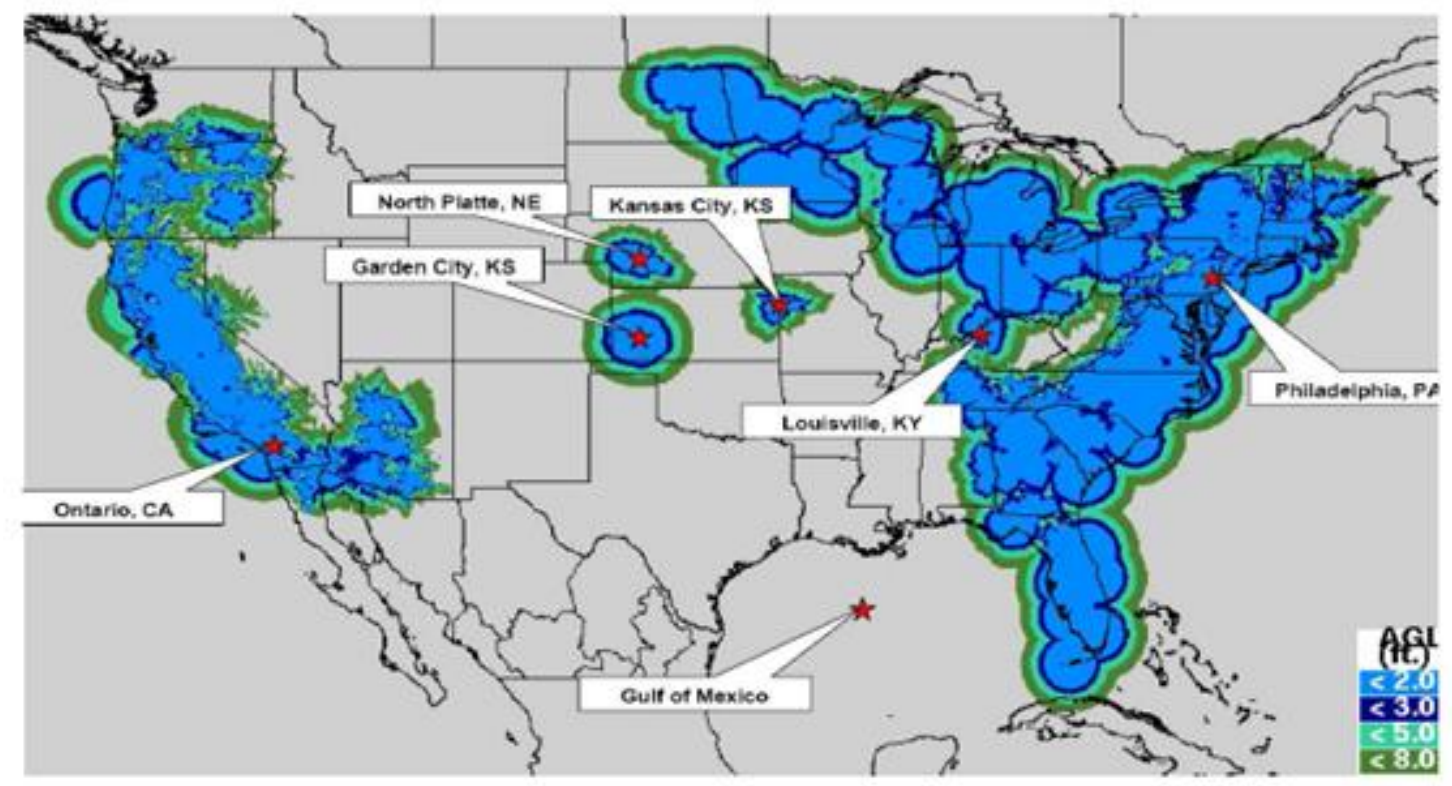

Fonte: $A D S$-B- automatic dependent surveillance broadcast : estudo do impacto em Portugal $^{10}$

Figura 11: Desenvolvimento do ADS-B na Europa

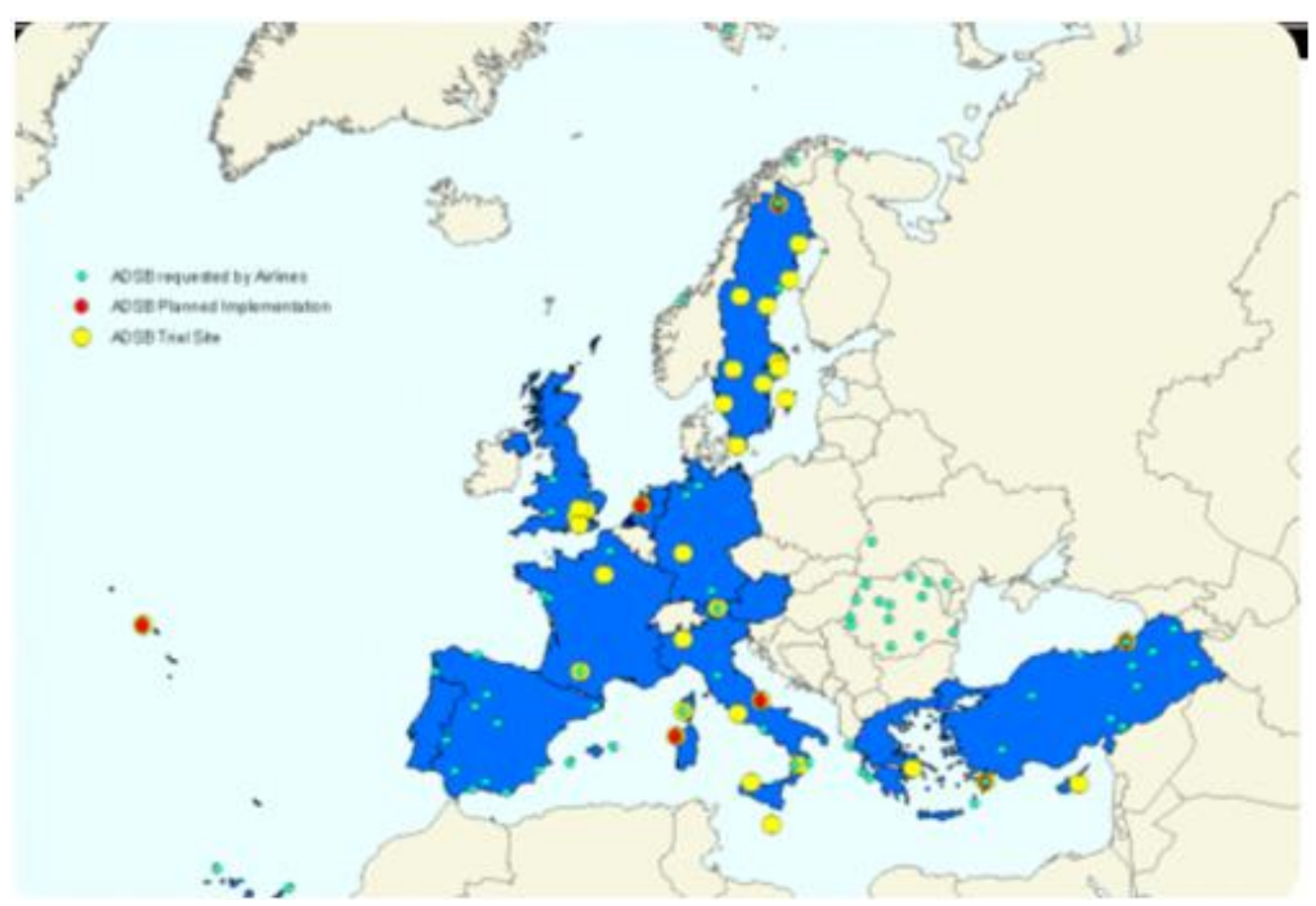

Fonte: $A D S-B$ - automatic dependent surveillance broadcast : estudo do impacto em Portugal ${ }^{10}$

\footnotetext{
${ }^{10}$ RODRIGUES, Cláudia Vanessa Coutinho. ADS-B-automatic dependent surveillance broadcast : estudo do impacto em Portugal. Universidade da Beira Interior. Covilhã: Junho 2010. Disponível em: <http://ubibliorum.ubi.pt/handle/10400.6/3819>.
} 


\section{Considerações finais}

O avião é um meio de transporte muito seguro. Entretanto, para atingir seu objetivo, que é o de transportar pessoas com regularidade, eficiência e segurança se faz necessário um conjunto de recursos humanos e tecnológicos.

Diante desse quadro, percebeu-se que os sistemas analisados e utilizados no controle de tráfego aéreo necessitam de melhorias ou mesmo de mudança e da implementação de um novo sistema de controle de tráfego aéreo.

Os modelos propostos e analisados como melhoria baseiam-se no uso do satélite, para melhor precisão do posicionamento das aeronaves que estiverem voando no espaço aéreo brasileiro, bem como otimizar a velocidade de processamento dessas informações, pois um equipamento com processamento local na aeronave terá atualizações de posição por meio das informações do satélite. Vale salientar que, para que um sistema desse porte seja implementado, é necessário apoio das empresas aéreas, bem como do Governo.

Essas modificações trarão benefícios tanto para os controladores de voos, quanto para as empresas aéreas. Os controladores terão um sistema confiável, diminuindo ou até mesmo eliminando o sofrimento psicofísico e o acúmulo de estresse implicado pelo trabalho desses profissionais. As companhias aéreas serão beneficiadas, pois os controladores de tráfego com informações precisas emitirão autorizações que diminuem o tempo de voo e, consequentemente, o consumo de combustível, o que irá refletir, consideravelmente, no fator econômico envolvido nas operações de transporte aéreo, além de minimizar os riscos e custos com seguros e procedimentos aeroportuários.

Tendo em vista este trabalho ser uma pesquisa de revisão bibliográfica dos sistemas e softwares, atualmente empregados no controle de tráfego aéreo brasileiro, possíveis contribuições ou melhorias podem seguir, como adição de outras funcionalidades não empreendidas neste trabalho.

\section{Referências}

[1] IBGE. Sinopse do Censo Demográfico 2010. Instituto Brasileiro de Geografia e Estatística. IBGE, 2011. Disponível em: <http://www.ibge.gov.br/home/estatistica/populacao/censo2010/sinopse.pdf>. Acesso em: 10 ago. 2016.

[2] SALGADO, Lucia Helena. Caos aéreo e tragédia dos comuns: falhas de mercado e de governo. Instituto de Pesquisa Econômica Aplicada (Ipea): Brasília, 2009. Disponível em: <http://repositorio.ipea.gov.br/handle/11058/1566>. Acesso em: 10 ago. 2016.

[3] MCKINSEY\& COMPANY. Estudo do Setor de Transporte Aéreo do Brasil: Relatório Consolidado. Rio de Janeiro: 2010. Disponível em: <http://www.bndes.gov.br/SiteBNDES/export/sites/default/bndes_pt/Galerias/Arquivos/empresa/pesquisa/ chamada3/relatorio_consolidado.pdf>. Acesso em: 10 ago. 2016.

[4] MINISTÉRIO DO TURISMO. Fundação Getúlio Vargas. Documento referencial Turismo no Brasil 2011/ 2014. Brasília, DF:2010, $160 \quad$ p. Disponível <http://www.dadosefatos.turismo.gov.br/export/sites/default/dadosefatos/outros_estudos/downloads_outros estudos/Turismo_no_Brasil_2011_-_2014_sem_margem_corte.pdf>. Acesso em: 10 ago. 2016.

[5] OXFORD. Economic Benefits from Air Transport in Brazil. Oxford Economics, 2011.Disponível em: <https://www.iata.org/policy/Documents/Benefits-of-Aviation-Brazil-2011.pdf>. Acesso em: 10 ago. 2016.

[6] GALLO, Fabrício. As preocupações com a integração territorial do Brasil e o pensamento geopolítico nacional: a relevância da aviação na ocupação do país. Entre-Lugar, Dourados, MS, ano 1, n. 2, p. 57-74, $2^{\circ}$ semestre de 2010. Disponível em: <http://www.periodicos.ufgd.edu.br/index.php/entrelugar/article/viewFile/757/745>. Acesso em: 10 ago. 2016.

[7] ABREU, Emmanuelle Leite Viana. Análise sistêmica do setor aéreo brasileiro: propostas para o planejamento do setor. 2008. 157 f. Dissertação (Mestrado em Transportes) -Universidade de Brasília, Brasília, 2008. Disponível em: <http://repositorio.unb.br/handle/10482/5125>. Acesso em: 10 ago. 2016.

Revista Brasileira de Computação Aplicada (ISSN 2176-6649), Passo Fundo, v. 8, n. 3, p. 66-84, abr. 201681 
[8] POGIANELO, Marcus Luiz; MÜLLER, Carlos. Análise do espaço aéreo em área de controle terminal por meio de simulação "fast time” - estudo de caso na TMA - Recife. Sitraer7 (2008) 66-78 - Tr. 143. Disponível em: <http://www.tgl.ufrj.br/viisitraer/pdf/143.pdf〉. Acesso em: 10 ago. 2016.

[9] MEDAU, João Carlos. Análise de capacidade do lado aéreo de aeroportos baseada em simulação computacional: aplicação ao aeroporto de São Paulo - Congonhas. São Paulo: 2011. Disponível em: <http://www.teses.usp.br/teses/disponiveis/3/3138/tde-25082011-134443/pt-br.php>. Acesso em: 10 ago. 2016.

[10] OLIVEIRA, Amâncio Jorge de; ONUKI , Janina; AMORIM, Sônia Naves David. A crise do transporte aéreo - 2006 e 2007. Casacoteca de Gestão Pública: 2009. Disponível em: $<$ http://casoteca.enap.gov.br/index.php?option=com_multicategories\&view=article\&id=15:a-crise-dotransporte-aereo-no-brasil-2006-2007-\&catid=17:negociacao\&Itemid=12>. Acesso em: 10 ago. 2016.

[11] CAMARGOS, M. A.; MINADEO, R. Aquisições na aviação civil brasileira: uma análise da trajetória da Gol e da Varig até a sua aquisição. Gestão e Sociedade, v. 1, n. 2, p. 1-30, 2007. Disponível em: <http://www.spell.org.br/documentos/ver/10281/aquisicoes-na-aviacao-civil-brasileira--uma-analise-datrajetoria-da-gol-e-da-varig-ate-a-sua-aquisicao/i/en>. Acesso em: 10 ago. 2016.

[12] STEIN, Leila de Menezes; PERA, Géssica Trevizan. Greve e Complexidade: Dilemas do movimento dos controladores de vôo no Brasil (2006-2007). REDD - Revista Espaço de Diálogo e Desconexão,

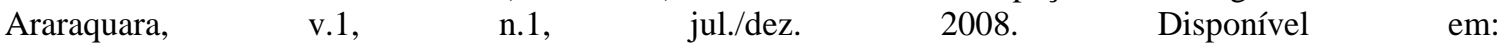
<http://seer.fclar.unesp.br/redd/article/viewFile/1077/883>. Acesso em: 10 ago. 2016.

[13] FERREIRA FILHO, Bemildo Alvaro. O controle de tráfego aéreo brasileiro entre setembro de 2006 e março de 2007: a ruptura operacional, o modelo administrativo e perspectivas. Journal of Transport Literature, América do Norte, 5, fev. 2011. Disponível em: <http://www.pesquisaemtransportes.net.br/relit/index.php/relit/article/view/jv5n2p11>. Acesso em: 10 ago. 2016.

[14] REBELLO, Luiz Helena Boueri. Uma abordagem ergonômica em controle de tráfego aéreo em função das inovações tecnológicas. COPPE/UFRJ, $2007 . \quad$ Disponível <http://www.abepro.org.br/biblioteca/enegep1998_art263.pdf>. Acesso em: 10 ago. 2016.

[15] SIEWERDT , Eno. Vigilância aérea. Desmistificando as tecnologias de vigilância dependente automática por radiodifusão e multilateração. Sitraer 7 (2008) 407-419 - Tr. 426. Disponível em: <http://www.tgl.ufrj.br/viisitraer/pdf/426.pdf>. Acesso em: 10 ago. 2016.

[16] GOUVEIA, Flávia; KANASHIRO, Marta. Espaço aéreo sob controle: segurança, tecnologia e riscos. ComCiência. Disponível

em: <http://www.cienciamao.usp.br/tudo/exibir.php?midia=com\&cod=_espacoaereosobcontrolesegurancatecno logiaeriscosrevistacomciencian84fev2007>. Acesso em: 10 ago. 2016.

[17] LIMA, Márcio P.; FONTES, Cristiano H. de O.;SCHNITMAN, Leizer. A lógica fuzzy do tipo 2 e um estudo de caso aplicado ao controle de tráfego aéreo. Programa de Pós-Graduação em Mecatrônica Universidade Federal da Bahia (UFBA). Disponível <http://fei.edu.br/sbai/SBAI2007/docs\%5C60100007.pdf>. Acesso em: 10 ago. 2016.

[18] WERUTSKY, André Gustavo Rolim. A responsabilidade civil do estado no acidente aéreo. Unirriter: Canoas, 2008. Disponível em: <http://www.sntpv.com.br/clipping/responsabilidade_civil.pdf >. Acesso em: 10 ago. 2016.

[19] SILVA, A. M. G.. Sistema de simulação acelerado para análise de fluxo de tráfego aéreo. INPE: 2001. Disponível em:

$<$ http://mtcm16b.sid.inpe.br/rep/sid.inpe.br/iris@ 1913/2005/08.01.12.31?mirror=cptec.inpe.br/walmeida/2003/04.25.1 7.13\&metadatarepository=sid.inpe.br/iris@1913/2005/08.01.12.31.14>. Acesso em: 10 ago. 2016.

[20] PEREIRA, Eduardo Afonso; SIMONATO, Juliano Boscaine; BERBEL, Lucas Thijssen. O limite de autorização nas operações aéreas: O Caso Gol 1907. Conexão SIPAER, América do Norte, 1, nov. 2009. Disponível em: <http://inseer.ibict.br/sipaer/index.php/sipaer/article/view/10>. Acesso em: 10 ago. 2016. 
[21] RIBEIRO, Vitor Filincowsky. Decisão colaborativa com utilização de Teoria dos Jogos para o sequenciamento de partidas em aeroportos. UNB, 2013. Disponível em: <http://repositorio.unb.br/handle/10482/13661>. Acesso em: 10 ago. 2016.

[22] RIBEIRO, Vitor Filincowsky et al. Previsão de cenário para o Controle de Tráfego Aéreo do CINDACTA I. UNB, Brasília, 2008. Disponível em: <http://www.tgl.ufrj.br/viisitraer/pdf/393.pdf >. Acesso em: 10 ago. 2016.

[23] BRASIL. Tribunal de Contas da União. Auditoria no sistema de tratamento e visualização Radar X-4000 / Tribunal de Contas da União. Relator Ministro Benjamin Zymler. - Brasília: TCU, Secretaria de Fiscalização de Tecnologia da Informação, 2008. Disponível em: <http://portal2.tcu.gov.br/portal/pls/portal/docs/2053228.PDF>. Acesso em: 10 ago. 2016.

[24] GUERRA, José Ricardo Gramelich. Metodologia para a organização de um banco de dados com aplicativos para o planejamento de vôo. 2008. 87 f. Monografia (Especialização em Gestão da Aviação Civil)-Universidade de Brasília, Brasília, 2008. Disponível em: <http://bdm.unb.br/handle/10483/1614>. Acesso em: 10 ago. 2016.

[25] MOTTER, Arlete Ana; GONTIJO, Leila Amaral. Análise ergonômica de uma ferramenta de trabalho no controle de tráfego aéreo: percepção dos operadores e contribuições para a carga de trabalho. Revista Produção Online, Florianópolis, v. 12, n. 4, p. 856-875, nov. 2012. ISSN 16761901. Disponível em: <http://producaoonline.org.br/rpo/article/view/541>. Acesso em: 10 ago. 2016.

[26] CHAN, Y. K; KOO, V. C. An Introduction to Synthetic Aperture Radar (SAR). Progress In Electromagnetics Research B, Vol. 2, 27-60, 2008. Disponível em: <http://www.jpier.org/PIERB/pier.php?paper=07110101>. Acesso em: 10 ago. 2016.

[27] MINISTÉRIO DO TURISMO. Universidade de Campinas - NEIT/UNICAMP. O transporte aéreo no Brasi: panorama geral, avaliação da competitividade e propostas de políticas públicas para o setor. $<$ http://www.turismo.gov.br/sites/default/turismo/o_ministerio/publicacoes/downloads_publicacoes/O_TR ANSPORTE_AxREO_NO_BRASIL_PANORAMA_GERALx_AVALIAxO_DA_COMPETITIVIDADE _E_PROPOSTAS_DE_POLxTICAS_PxBLICAS_PARA_O_SETOR.pdf>. Acesso em: 10 ago. 2016.

[28] MAYEDA, Leonardo; TRINTINALIA, Raphael Mielle; MASUKI, Thiago Koji. Cenário atual dos sistemas de gerenciamento de tráfego aéreo e as perspectivas para o futuro. USP - STOA: Disponível em: <http://moodle.stoa.usp.br/file.php/930/Artigos/pdfs/CENARIO_ATUAL_DOS_SISTEMAS_DE_GEREN CIAMENTO_DE_TRAFEGO_AEREO_E_AS_PERSPECTIVAS_PARA_O_FUTURO.pdf>. Acesso em: 10 ago. 2016.

[29] ROCHA, Guilherme Conceição. Principais Iniciativas para Aumento da Segurança Operacional no Transporte Aéreo. Instituto Técnico da Aeronáutica - XII SIGE - Simpósio de Aplicações Operacionais em Áreas de Defesa, são José dos Campos, 2010. Disponível em: $<$ http://www.dcabr.org.br/download/publicacoes-tecnicas/principais-iniciativas-para-aumento-daseguranca-operacional-no-transporte-aereo.pdf>. Acesso em: 10 ago. 2016.

[30] BASTOS, Alexandre L. D; BAUM, Derick M. Tráfego Aéreo. ABP, 2007. Disponível em: <http://www.abp.esp.br/userfiles/files/Trafego_Aereo.pdf>. Acesso em: 10 ago. 2016.

[31] MEDEIROS, Felipe Leonardo Lobo; SANTOS, Carmen Lucia Ruybal dos; MARCHI,Mônica Mariade; PINTO, Maria José. Algoritmo Genético Aplicado à Otimização da Cobertura do Sinal Gerado por Radares Terrestres. XXV Congresso da Sociedade Brasileira de Computação - SBC: São Leopoldo, 2005. Disponível em: <http://www.lbd.dcc.ufmg.br/colecoes/enia/2005/051.pdf>. Acesso em: 10 ago. 2016.

[32] COSTA, Rodrigo Pintus Gonçalves da et al. Um modelo de aplicação do receptor ADS-B para antecipação de eventos aeroportuários. XI SITAER: 2012. Disponível em: <http://www.sysport.com.br/Papers/XI\%20Sitraer.pdf>. Acesso em: 10 ago. 2016.

[33] REBELLO, Luiz Helena Boueri. Uma abordagem ergonômica em controle de tráfego aéreo em função das inovações tecnológicas. COPPE/UFRJ, $2007 . \quad$ Disponível em: <http://www.abepro.org.br/biblioteca/enegep1998_art263.pdf>. Acesso em: 10 ago. 2016. 
[34] SARAIVA, Ivan et al. Simulação da trajetória das ondas de propagação do radar meteorológico - Estudos de chuvas intensas. 2005. Disponível em: <http://www.cbmet.com/cbm-files/14f8be835167345a34235eded4227f3ec0.pdf>. Acesso em: 10 ago. 2016.

[35] ADINOLFI, A. G.; SOUZA, M. L. O. Uma discussão preliminar sobre o uso de engenharia de requisitos para reduzir riscos no desenvolvimento de futuros sistemas de navegação aeronáutica. In: WORKSHOP EM ENGENHARIA E TECNOLOGIA ESPACIAIS, 2. (WETE), São José dos Campos São José dos Campos. Anais... São José dos Campos: INPE, 2011. DVD. ISSN 2236-2606. Disponível em: <http://urlib.net/J8LNKAN8RW/3ARN96U>. Acesso em: 10 ago. 2016.

[36] VISMARI, Lucio Flavio. Vigilância dependente automática no controle de tráfego aéreo: avaliação de risco baseada em modelagem em redes de Petri fluidas estocásticas. São Paulo: 2007. Disponível em: <http://www.teses.usp.br/teses/disponiveis/3/3141/tde-08012008-153718/pt-br.php >. Acesso em: 10 ago. 2016.

[37] RODRIGUES, Cláudia Vanessa Coutinho. ADS-B- automatic dependent surveillance broadcast : estudo do impacto em Portugal. Universidade da Beira Interior. Covilhã: Junho 2010. Disponível em: <http://ubibliorum.ubi.pt/handle/10400.6/3819>. Acesso em: 10 ago. 2016. 